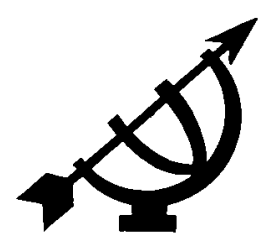

\title{
Vriendskap: waarom is dit so skaars en hoe kan dit in ere herstel word? ${ }^{1}$
}

\author{
B.J. van der Walt \\ Skool vir Filosofie \\ Potchefstroomkampus \\ Noordwes-Universiteit \\ POTCHEFSTROOM \\ E-pos: hannah@intekom.co.za
}

\begin{abstract}
Friendship: Why is it so rare and how should it be restored to a place of honour?
\end{abstract}

Different authors mention the fact that nowadays friendship is ignored and rarely celebrated. In trying to improve this sad state of affairs, this article proceeds through the following steps: A brief historical review which reveals that in the past friendship was confused with other relationships and its real value was not acknowledged by Christians. From the perspective of a Christian philosophy of society, it is indicated that friendship is a unique relationship of love, which should be clearly distinguished from other forms of love, for instance the love of marriage partners, brotherly love and neighbourly love in general. This discussion is followed by a structural analysis of the relation of friendship, indicating what real friendship entails. In the light of the preceding, it becomes possible to discern between acceptable forms of friendship and unacceptable "friendships". The next section provides, apart from the already mentioned historical causes, different reasons for the rareness of friendships in contemporary Western societies. In conclusion, the special value of friendship is emphasised as being a unique gift of God and simultaneously an important human obligation.

1 Met groot dank erken ek die waardevolle insigte asook die verwysing na belangrike bronne - waardeur hierdie artikel verryk, verdiep en verbreed is van my ontslape vriend, Nicolaas Theodor (Theo) van der Merwe (03/11/193214/09/2004). Toe hy alreeds siek was, het hy nogtans, op sy kenmerkende en deeglike manier, die oorspronklike manuskrip met my bespreek. In dankbare herinnering aan wat sy opregte, onbaatsugtige vriendskap die afgelope veertig jaar vir my beteken het, word hierdie artikel aan hom opgedra. 


\section{Opsomming}

Vriendskap: waarom is dit so skaars en hoe kan dit in ere herstel word?

Die feit dat vriendskap volgens talle skrywers vandag iets skaars geword het, noodsaak die volgende stappe in 'n poging om die situasie te verbeter: 'n Kort historiese oorsig wat aantoon dat alreeds in die verlede onder Christene meningsverskil en selfs verwarring was oor wat vriendskap behels en wat die waarde daarvan is. Vervolgens word vanuit 'n Christelike samelewingsfilosofie aangetoon dat vriendskap nie iets minderwaardigs of onbelangriks is nie, maar 'n eiesoortige menslike liefdesverhouding, wat duidelik van ander vorme van liefde, soos huweliksliefde, broederlike liefde en naasteliefde in die algemeen, onderskei moet word. Daarna volg 'n struktuuranalise van die vriendskapsverhouding, waaruit duidelik blyk wat ware vriendskap inhou. In die lig daarvan word vervolgens onderskei tussen aanvaarbare vorms van vriendskap en onaanvaarbare "vriendskappe". Die volgende hoofpunt gee verskillende redes waarom egte vriendskap, afgesien van die reeds genoemde historiese redes, in die hedendaagse Westerse samelewings so 'n seldsame verskynsel is. Ten slotte word die aandag daarop gevestig dat vriendskap van besondere waarde is, naamlik 'n wonderlike gawe van God. Terselfdertyd hou dit egter ook 'n dringende opgawe aan ons in.

\section{Inleiding: Vriendskap het 'n probleem geword}

Talle skrywers vestig die aandag daarop dat ware vriendskap skaars geword het. Lewis (1990:55) vat die situasie soos volg saam:

To the Ancients, friendship seemed the happiest and most fully of all human loves; the crown of life and the school of virtue. The modern world, in comparison, ignores it. We admit of course that besides a wife and family a man needs a few 'friends'. But the very tone of the admission, and the sort of acquaintanceships which those who make it would describe as 'friendships', show clearly that what they are talking about has very little to do with the Philia which Aristotle classified among the virtues or that Amicitia on which Cicero wrote a book. It is something quite marginal; not a main course in life's banquet; a diversion; something that fills up the chinks of one's time.

(Olthuis, 1975:108, 109) huldig dieselfde mening:

... the modern world generally ignores friendship. We admit that everyone needs a few friends, but we don't become very excited by their presence or absence. Today we rarely celebrate friendship ... Very few sing the praises of friendship because very few have experienced its heights. 
Soortgelyke uitsprake kan gelees word in byvoorbeeld Woldring (1994:11), Van der Walt (2000:417) en Linden (2003:162). Laasgenoemde skryf onder andere: "close friendship ... is rarely experienced".

Oor die leemte aan intieme vriendskappe word ook in die Christelike etiese lektuur geskryf. Brillenburgh Wurth (1953:137) skryf reeds in 1953 dat dit opmerklik is hoe weinig daar oor vriendskap in Christelike kringe geskryf word. Belangrike ander werke oor Christelike etiek (vgl. byvoorbeeld Fairweather \& McDonald, 1984; Henry, 1965; Reid, 1981 en Stob, 1978) bevestig dié opmerking.

Dieselfde tendens geld ook in die gereformeerde teologiese wêreld. In Geesink (1907-1908) se vierdelige Van 's Heeren ordinantien vind 'n mens nie 'n woord oor vriendskap nie. In dieselfde skrywer se lywige tweedelige Gereformeerde Etiek (Geesink, 1931) word slegs twee bladsye (Geesink, Deel 2, p. 295-296) aan vriendskap afgestaan. In Aalders (1947) se etiek word geen woord oor vriendskap gerep nie. Dieselfde is die geval met Brillenburg Wurth (1948-1951) se driedelige Het Christelijk leven - dit behandel uiteenlopende onderwerpe, maar nie vriendskap nie. Ook latere etiese werke uit die gereformeerde teologiese kring in Nederland (vgl. byvoorbeeld Schippers, 1955 en Von Meyenfeldt, s.j.) bied niks oor vriendskap nie. Die situasie is nie beter in Suid-Afrika nie. Van Wyk (1986; 1991; 1998; 1999 en 2001), 'n toonaangewende Gereformeerde etikus, behandel byvoorbeeld in nie een van sy werke vriendskap nie. Tog is dit een van die belangrikste eties-gekwalifiseerde menslike verhoudings.

Die kernprobleem wat in hierdie artikel behandel word, is dus hoe dit moontlik is dat iets so noodsaakliks soos vriendskap, so min aandag van die meeste Christene ontvang. Die geskiedenis kan moontlik lig werp op dié raaisel.

\section{Vriendskap deur die eeue}

Die aanhaling hierbo uit Lewis (1990:55) het alreeds laat blyk hoe verskillend vriendskap gedurende die antieke Griekse en Romeinse tyd en die Christendom daarna waardeer is: in eersgenoemde geval is dit oorskat en in laasgenoemde onderskat.

\subsection{By die Grieke en Romeine}

Omdat die bedoeling van hierdie artikel is om die tradisionele Christelike visie op vriendskap te ondersoek, volg hier slegs enkele 
flitse oor vriendskap in die antieke tydperk (vir 'n kort, samevattende oorsig, vgl. Ritter, 1972:1106-1107).

Onder die antieke denkers het die filosoof, Aristoteles, seker een van die belangrikste bydraes gelewer (vgl. Woldring, 1994:37-49). Selfs hedendaagse skrywers oor vriendskap (vgl. byvoorbeeld Ladikos, 2000 en Stortz, 2002) gebruik weer die werk van Aristoteles as bron van inspirasie.

Afgesien van 'n groot verskeidenheid interpretasies van vriendskap in die ou tyd (vgl. Woldring, 1994:15-66), is vriendskap steeds beskou as 'n vorm van liefde. Die woord philos (vriend) kom van die Griekse werkwoord philein (om lief te hê). Die Latynse woord vir "vriend" is amicus, wat teruggaan op amor (liefde) en die werkwoord amare (om lief te hê). Die spesifieke vorm van liefde word egter nog nie nader gespesifiseer nie. Linden (2003: 157) beweer byvoorbeeld dat die woord philia by Aristoteles in die verlede verkeerdelik met "vriendskap" vertaal is, in plaas van gewoon met "liefde" in die algemene, breë betekenis. Die grondslag van vriendskap is korrek gesien as die psigiese aantrekkingskrag tussen twee mense.

Daar is dus baie te leer oor vriendskap by die Griekse en Romeinse denkers. Die belangrikste kritiek vanuit Christelike hoek was dat hulle té groot waarde aan hierdie intieme menslike verhouding toegeken het. Volgens Woldring (1994:15) kan 'n mens die belang wat hulle aan vriendskap gegee het vergelyk met die belang wat in die hedendaagse Weste aan die gesin gegee word, naamlik as "die hoeksteen van die samelewing". ' $n$ Belangrike rede vir dié mening is geleë in die aard van vriendskap, naamlik dat dit selektief is, terwyl God se liefdesgebod teenoor die naaste universeel is. Dit is egter ' $n$ feit dat die Christelike nadenke oor vriendskap, in reaksie teen die "oorskatting" daarvan in die Grieks-Romeinse wêreld, in die teenoorgestelde uiterste verval het, naamlik deur dit te onderskat.

\subsection{Vriendskap in die Christelike tradisie}

Voordat vasgestel word wat die Bybel self oor vriendskap leer, eers 'n vinnige blik op Christene se nadenke oor die saak. Vier prominente Christendenkers se standpunte word kortliks aan die orde gestel.

\subsubsection{Augustinus en sy invloed}

Al gaan die Christelike tradisie verder terug, sou ons die Christelike besinning oor vriendskap met die groot kerkvader, Aurelius Augustinus (354-430 n.C.), kon begin. (Vir 'n volledige uiteensetting 
sien Hartmann, 1955; McNamara, 1958; Woldring, 1994:69-78 en Andresen, 1973:128-130 wat nog meer literatuur onder Liebesbegriff by Augustinus bied.)

Vriendskap is volgens Augustinus belangrik - daarsonder sou die wêreld 'n woestyn gewees het. Omdat hy vriendskap as 'n geskenk van God beskou, mag vriendskap nie maar 'n sydelingse, terloopse verhouding in 'n Christen se lewe wees nie. Augustinus beskou vriendskap as 'n verhouding van wedersydse liefde, gegrond op 'n sekere gelykheid van belangstellings en ideale. Augustinus staan dus duidelik nog sterk onder die invloed van die Griekse en Romeinse filosowe se hoë waardering van vriendskap.

Ongelukkig vind ons egter alreeds by Augustinus 'n soort dualisme wat 'n beslissende invloed op die Christendom na hom sou hê. Om vir die Christen aanvaarbaar te wees, moet amicitia (vriendskap) verhef en op 'n hoër vlak, naamlik dié van caritas (liefde) gebring word. Hierdie gedagte is ' $n$ duidelike voorloper van die natuurgenadetema wat die lewe in twee terreine verdeel het, naamlik 'n natuurlike en 'n bo-natuurlike of geestelike terrein. Die natuurlike is die voortrap en die bo-natuurlike die vervolmaking. Volgens hierdie onbybelse dualisme is vriendskap iets natuurliks en alleen werklik vir 'n Christen aanvaarbaar wanneer dit deur sogenaamde bonatuurlike liefde tot God en die naaste gedra, omvorm en vervolmaak word. 2

Hierdie spanning tussen vriendskap (amicitia), wat selektief en eksklusief is en Christelike liefde (caritas), wat universeel geld, kom nog skerper na vore by 'n denker soos Ambrosius (339-397). Hierdie spanning bly ' $n$ probleem dwarsdeur die Christelike denke, maar veral gedurende die Middeleeue - 'n periode wat nog duideliker deur die dualisme van natuur-genade getipeer word.

Hierby moet egter gesê word dat die Middeleeuse en RoomsKatolieke denke ook 'n belangrike bydrae gemaak het toe dit oor die werking van vriendskap en liefde in die algemeen in 'n geloofskonteks besin het. Hierdie denke het verder beklemtoon dat vriendskapsliefde nie van 'n mens se verhouding tot God losgemaak

$2 \quad$ N.T. van der Merwe vestig (in 'n persoonlike gesprek op 17/07/2004) die aandag daarop dat hoewel Augustinus deur die Neo-Platonisme beïnvloed is, sy visie op vriendskap terselfdertyd sterk deur sy Christelike oortuigings bepaal is; ook dat juis as gevolg van die wyse waarop Augustinus se opvatting van vriendskap met die (Christelike) liefde saamhang, die "dualisme" in sy denke nie dieselfde as dié van die latere Middeleeuse Christendom is nie. 
mag word nie. Deur dié verband te benadruk (al is dit ook dualisties uitgewerk) is só 'n visie veel beter as die hedendaagse sekularistiese standpunt waarin vriendskap heeltemal geïsoleer word van die godsdienstige of religieuse verhouding tot God en tot ' $n$ horisontale verhouding tussen mense gereduseer en vervlak word.

Die feit dat die Renaissance na die Griekse en Romeinse kultuur se hoë waardering vir vriendskap teruggekeer het, het die reaksie by Christene daarteen tydens die sestiende-eeuse Reformasie net vergroot.

Drie moderne Christendenkers by wie hierdie onderwaardering van vriendskap nog steeds duidelik na vore kom, is E. Brunner, C.S. Lewis en G. Brillenburgh Wurth.

\subsubsection{E. Brunner}

Die spanning tussen vriendskap (iets "natuurliks") en (ware) Christelike liefde (iets "bo-natuurliks") wat ons alreeds by Augustinus gevind het, is ook weer by Brunner teenwoordig. Brunner, 'n dialektiese teoloog, is heelwaarskynlik ook sterk beïnvloed deur $\mathrm{S}$. Kierkegaard (1813-1855), die Deense irrasionalistiese Christenfilosoof, wat as die vader van sowel die eksistensialistiese filosofie as die dialektiese teologie beskou word. (Vir detail oor sy standpunt, vgl. Kierkegaard, 1962 en Woldring, 1994:129-143.)

Oor vriendskap skryf Brunner (1949:517-518) byvoorbeeld:

Friendship ... does not spring from ethical impulses but from our natural spiritual impulse. We are not driven to it by a sense of compulsion or duty, but we are drawn to certain people by a certain attraction ... Friendship begins with pleasure in the individuality of the other person ... From the point of view of faith, friendship is a natural fact which can only become ethical through the love of our neighbor. Real community, Agape, is foreshadowed, naturally in friendship ... (kursivering - BJvdW).

Vriendskap staan dus eintlik in spanning met die liefdesgebod. Dieselfde dilemma kom ook voor in die bekende boek van Nygren (1957).

\subsubsection{C.S. Lewis}

In sy bekende werk, The four loves (1990), worstel hierdie alombekende Christenskrywer ook met die probleem hoe die menslike vriendskapsliefde in verband gebring kan word met 
goddelike liefde - vgl. die hoofstuk oor "Friendship" - Lewis (1990: 55-84) - en die hoofstuk oor "Charity" - Lewis (1990:107-128).

Tereg beweer Lewis (1990:83) dat vriendskap 'n gawe van God is. Sy motivering hiervoor moet egter bevraagteken word as hy stel dat "Friendship, like all other natural loves, is unable to save itself ... it must ... involve the divine protection if it hopes to remain sweet". Vriendskap (appreciative love) is dus iets natuurliks en ongenoegsaam, teenoor die bo-natuurlike, goddelike liefde (charity) wat dit moet vervolmaak.

By sowel gift-loves en need-loves onderskei Lewis tussen natuurlike en bo-natuurlike liefde - 'n bevestiging dat ook hy nie aan die oeroue dualisme van die natuur-genadetema ontkom het nie. Hierdie afleiding word benadruk as (Lewis, 1990:122) skryf dat

... the Divine love does not substitute itself for the natural - as if we had to throw away our silver to make room for gold. The natural loves are summoned to become modes of charity while also remaining the natural loves they are.

Die dialektiese spanning wat die onbybelse natuur-genadetema veroorsaak, blyk hier duidelik. Aan die een kant is die sogenaamde natuurlike liefdes (in vriendskap en huwelik) iets goeds - dit mag nie opgehef word nie. Aan die ander kant is dit egter nie goed genoeg as hulle nie tot die genadesfeer verhef word nie. 'n Meer Bybelse visie sou wees dat ons in ons liefdesverhoudings in vriendskap en huwelik (en op baie ander terreine) aan God se gebod om mekaar lief te hê, moet gehoorsaam.

\subsubsection{G. Brillenburgh Wurth}

Bogenoemde dualisme is alreeds duidelik aan die begin van Brillenburgh Wurth (1953:137 e.v.) se kort hoofstuk oor "Liefde als vriendskap" en dit deurtrek sy hele betoog. Vriendskap is volgens hom van 'n "natuurlike" aard teenoor broederlike liefde, wat "geestelik" sou wees. Vriendskap is 'n blote "humane grootheid" (Wurth, 1953:137, 139). Hy stel dit soos volg:

Wij zouden het ook zo kunnen zeggen: in de vriendschap komt het specifieke en karakteristieke van de christelijke liefde niet zozeer uit als in de broederliefde of in de barmhartigheid of de vijandsliefde (Brillenburgh Wurth, 1953:137).

Hierteenoor moet gestel word dat alle soorte liefde iets mensliks ("human") is en dat vriendskap daarom geen minderwaardige soort liefde is nie - die Skrif bied daarvoor geen gronde nie (vgl. 2.3) - 
maar wel ' $n$ ander soort liefde as broederlike/susterlike of vyandsliefde.

Dit wil lyk asof dit juis die aard van vriendskapsliefde is wat veroorsaak dat ook Brillenburgh Wurth dit degradeer. Omdat vriende mekaar kies en omdat daar dus van voorkeure sprake is - iets wat nie van naasteliefde mag geld nie - sou dit daarom van minder waarde wees. Tog is hierdie veronderstelling van Brillenburgh Wurth ook problematies, omdat huweliksliefde ook op voorkeur vir 'n bepaalde persoon berus en hy dit nie daarom as minder belangrik of selfs verkeerd kan beskou nie.

Ten spyte daarvan - 'n bewys van hoe die natuur-bonatuurskema sy denke bepaal - hou hy vol:

Daarmee is ... de relatieve waarde van vriendschap gegeven. Vriendschap is stellig niet een van de hoogste vormen van liefde. En iets als de vriendschap mag daarom ook in ons leven nooit zó'n grote plaats innemen, dat onze overige liefdetaak daardoor in het gedrang komt (Brillenburg Wurth, 1953:138).

Wanneer 'n mens van die onbybelse natuur-genade tweeterreineleer bevry is, is dit nie nodig om tussen laere/hoëre, onbelangrike/belangrike soorte liefdes te moet kies nie. Dan word dit moontlik om te erken dat daar verskillende godgegewe gestaltes van die liefde bestaan, wat elk eiesoortig van aard is en dus ewe belangrik is vir ' $n$ volle Christelike lewe. Dit is baie belangrik dat die verwarring tussen die verskillende soorte liefdes opgelos word, want dit is een van die belangrike redes waarom vriendskap so onderwaardeer word.

\subsection{Die Bybel oor vriendskap}

Voordat op die aard van die verwarring ingegaan word, is dit nodig om eers te kyk wat die Bybel self oor vriendskap leer. Uit die Bybel blyk dit duidelik dat dit verkeerd is om, soos in die Christelike tradisie, vriendskap as iets minderwaardigs te beskou. Slegs enkele flitse uit die Skrif word gegee om dié verkeerde persepsie te weerlê (vir meer besonderhede, vergelyk Anoniem, 1982:271-272 en Adams, Irwin \& Walters, 1968:237-238).

- Die Bybelskrywers was terdeë daarvan bewus dat ook vriendskap deel het aan die sonde. Jeremia $(9: 4,5)$ byvoorbeeld sê dat 'n mens nie eers meer op jou vriende kan vertrou nie. Miga (7:5) stel dit dat 'n mens op geen vriend meer moet staatmaak nie. (Volgens hierdie tekste veronderstel vriend- 
skap trou en integriteit.) Spreuke 18:24 waarsku dat 'n mens moet onderskei tussen blote maats of mooiweersvriende wat jou kan teleurstel en 'n vriend wat nader is as 'n broer. (Die trou van 'n vriend kan dus sterker wees as die liefde van 'n bloedbroer.) Volgens Deuteronomium 13:6 kan 'n mens se "vriende" jou ook verlei - selfs tot afgodediens.

- Teenoor "mooiweersvriendskap" is ware vriendskap, as 'n gawe van God self (vgl. Job 6:14), van besondere waarde. Al het Job se vriende nie begryp wat met hom gebeur en waarom nie, het hulle hom tog in liefde probeer ondersteun (vgl. Job $2: 12,13)$. Christus sê self dat daar geen groter liefde is as om jou lewe vir 'n vriend/in te gee nie (Joh. 15:13). Vriendskapsliefde - trou tot die dood toe - is beslis nie deur Hom as derderangse liefde beskou nie.

- $\quad$ Uit die woorde van Christus blyk dat die gestalte van liefde in die geval van vriendskap, trou is. Hierdie trou moet wedersyds geld. Dawid kla in Psalm 55:13-15 dat dit nie 'n vyand is, iemand van wie 'n mens dit kan verwag, wat hom verraai het nie, maar sy goeie vriend met wie hy so nóú verbonde was.

- $\quad$ Volgens die Skrif beteken dit nie dat vriende mekaar nie mag teregwys nie. Spreuke 27:5, 6 sê dat 'n mens juis op iemand wat jou soms moet teengaan, kan reken. Ook Spreuke 27:17 gebruik 'n treffende beeld: soos yster yster slyp, só slyp vriende mekaar ook.

- $\quad$ As in Deuteronomium 13:6 (OAV) gepraat word van "jou vriend wat soos jou eie siel is", kom die grondslag van ware vriendskap, naamlik geesverwantskap, duidelik na vore.

- $\quad$ Indien vriendskap nie as 'n belangrike menslike verhouding beskou word nie, waarom is die Bybel dan positief oor die liefde van Jonatan vir Dawid (vgl. 1 Sam. 19, 20) en Dawid se groot liefde vir sy vriend Jonatan? In sy klaaglied ná Jonatan se dood, sê Dawid: "Ek is bedroef oor jou, my broer, Jonatan. Jy was baie na aan my hart. Jou liefde was vir my wonderliker as die liefde van enige vrou" (2 Sam. 1:26). Nêrens word wat Dawid hier sê, deur die Bybel gekorrigeer nie. Ook in die Nuwe Testament lees ons van die liefde tussen Petrus en Andreas, Filippus en Natanael, sonder enige negatiewe kommentaar dat dit nie iets goeds was nie.

- $\quad$ Dit word nog onmoontliker om op grond van die Skrif die standpunt te verdedig dat vriendskap iets onbelangriks is wanneer ons lees dat God self Abraham sy vriend noem 
(2 Kron. 20:7; Jes. 41:8; Jak. 2:23). Christus noem nie net sy dissipels sy vriende nie (Joh. 15:14, 15), maar daar staan ook dat Hy sommige van hulle op 'n besondere wyse liefgehad het (Joh. 13:23). Behalwe sy dissipels, het Hy ook ander vriende soos Marta, Maria en Lasarus gehad (vgl. Joh. 11:11).

Uit hierdie enkele flitse is dit duidelik dat die Bybel vriendskap nêrens degradeer nie, maar eerder hoog waardeer. Toegerus met hierdie Bybelse perspektiewe kan die misverstande en verwarrings rondom vriendskap en die gevolglike verwaarlosing daarvan in die Christelike tradisie duideliker raakgesien word.

\section{Vier verwarrings in die Christelike tradisie reggestel}

Vier verwarrings behoort uit die weg geruim te word:

- die gedagte dat vriendskap, as iets "natuurliks", van 'n laere orde as ander soorte liefde sou wees;

- die verwarring tussen vriendskap en naasteliefde in die algemeen;

- die gedagte dat vriendskap in kompetisie met die huwelik en gesin sou wees; en

- die gebrek aan 'n duidelike onderskeid tussen vriendskap en broederlike/susterlike liefde.

\subsection{Vriendskap gedegradeer in vergelyking met ander soorte liefde}

Aangesien vriendskap 'n menslike verhouding is wat deur God ingestel is, mag ons dit nie devalueer nie. Een manier om God lief te hê is om goeie, getroue vriende te wees. In vriende se liefde vir mekaar, nie apart daarvan nie, het hulle God ook lief en beantwoord hulle aan sy liefdesgebod.

Die onderskeid tussen "natuurlike" liefde (vriendskap) en "geestelike" liefde (ander vorme van liefde) is onbybels. Olthuis (1975:119120) beskryf dié onderskeid bondig soos volg:

Dividing life into things natural and spiritual is contrary to the basic thrust of the Scriptures. When Paul told the Colossian believers to seek the things above where Christ is, he did not urge them to leave the world. On the contrary, he called them to live in a spiritual way in all of life's relationships. Spiritual does not refer to an additional, higher realm; instead it describes a life in its totality driven, motivated and guided by the love of God. If all our relations 
are spiritual - driven by the love of God - there must be a place for genuine, renewed friendships. The only important question is whether it is moved by the love of God or gripped by the lie of the Devil.

\subsection{Die verskil tussen vriendskap en naasteliefde in die algemeen}

Baie Christene vereenselwig vriendskap met Christus se sentrale liefdesgebod dat ons ons naaste moet liefhê soos onsself ( $\mathrm{vgl}$. in hierdie verband Matt. 22:37-40). Op dié wyse gaan die unieke aard van vriendskap egter verlore. Verder moet alle menslike aktiwiteite dan volgens hierdie model van vriendskap genormeer word.

Hierdie verwarring kom nie net by Christene voor nie. Dit kom na vore in die (humanistiese) gedagte dat almal "broeders" van mekaar is en by kommuniste wat mekaar as "kamerade" aanspreek.

In die hedendaagse wetenskaplike lektuur heers hierdie verwarring ook. Natuurlik kan vanuit verskillende vakgebiede oor vriendskap besin word. Vriendskap moet egter in sy uniekheid as iets met 'n eiesoortige aard erken word en nie as die (enigste) oplossing vir allerlei andersoortige menslike verhoudings beskou word nie. In ons individualistiese tyd met sy gebrek aan gemeenskap word vriendskap gesien as 'n oplossing vir baie uiteenlopende probleme probleme op sportgebied (vgl. Pienaar, 1995 en Steyn, 1996), maatskaplike probleme (vgl. Dunstan \& Nieuwoudt, 1993), siekte (vgl. Linden, 2003), psigologiese steurnisse (vgl. Liddell, 1987) en die versorging van vigslyers (vgl. Decker, 1997). Ook word vriendskap ingespan vir die oplossing van sosiologiese vraagstukke (vgl. Wuthnow, 2003), leierskapsvraagstukke (vgl. Dreyer, 2002); word dit betrek op politieke terrein as "burgervriendskap" (vgl. Woldring, 1994:183-191) en selfs deur kriminoloë toegepas op die gevangeniswese (vgl. Ladikos, 2000).

Vriendskap kan egter nie die sentrale model vir ons hele lewe wees nie. Niemand kan 'n spesiale (vriendskaps)verhouding hê met elkeen wat hy/sy ontmoet nie. Indien ons vriendskap met liefde tot die naaste verwar, skakel ons die verskeidenheid in die menslike samelewing uit en maak daarvan 'n smaaklose, kleurlose eenvormigheid. Dan word "vriendskap" iets betekenisloos - as elkeen my vriend is, is niemand (werklik) my vriend nie.

Die Bybelse gebod van naasteliefde veronderstel 'n verskeidenheid van liefdes. Nie vriendskapstrou nie, maar billike geregtigheid (ook 'n vorm van liefde) behoort die norm te wees in geregshowe. 
Kinders is nie hulle ouers se vriende nie, maar is aan hulle kinderliefde verskuldig. 'n Sakeonderneming kan ook nie op vriendskap gebou wees nie, omdat ekonomiese beginsels daarin moet geld (vgl. Olthuis, 1975:121). Broederlike of susterlike liefde (in byvoorbeeld die kerk) is geloofsliefde. Hierdie soort liefde verskil van etiese broeder- of susterliefde in die gesin. Hoewel 'n mens nie jou vyande as vriende kan hê nie, vereis die Bybel van ons vyandsliefde!

Saamgevat: Indien nie tussen die breë, omvattende gebod van liefde tot die naaste en vriendskap (net één van die baie maniere om God en die naaste lief te hê) onderskei word nie, word vriendskap beroof van sy spesifieke betekenis en lei dit ook tot 'n uitholling van die liefdesgebod. (Die gebod sou dan gelui het dat ons ons vriende moet liefhê soos onsself.) Sodanige vervlakking van die gebod tot naasteliefde kan maklik tot stroperige sentimentaliteit lei.

Behalwe die onderskeid mag die verband tussen die verskillende gestaltes van die liefde egter ook nie vergeet word nie ${ }^{3}$ - so iets kan gebeur, omdat 'n intermenslike verhouding soos vriendskap (wat eties gekwalifiseerd is met trou as die norm) 'n eie "kleur" (modale differensiëring) in verskillend gekwalifiseerde verhoudinge en samelewingsverbande aanneem.

Die verhouding tussen kennisse is logies-sosiaal van aard. Die verhouding tot ' $n$ maat is sosiaal gekwalifiseerd. By kamerade staan die polities-militêre voorop. In die geval van kollegas kan die akademiese of ekonomiese voorop staan en in die geval van goeie buurmanskap is die ruimtelike verhouding die belangrike.

In die lig hiervan kan die voorbeelde hierbo soos volg gewysig word: Kinders en ouers is wel vriende, maar ook méér as dit. Huweliksgenote moet ook mekaar se (beste) vriende wees, maar is terselfdertyd baie méér as dit. Vriendskap speel selfs in 'n ekonomiese konteks (as vertroue in mekaar) 'n belangrike rol. Die navorsers wat vriendskap as 'n oplossing vir probleme op uiteenlopende lewensterreine aanbied, beklemtoon dus wel 'n belangrike waarheidsmoment.

3 Ook hierdie belangrike insig het ek te danke aan 'n gesprek met Van der Merwe (vgl. voetnoot 1). 


\subsection{Vriendskapsliefde en huweliksliefde}

Wanneer vriendskap en (naaste)liefde nie onderskei word nie, kan ook nie tussen die vriendskapsverhouding en die huweliksverhouding onderskei word nie en gevolglik ook nie die regte verband tussen die twee gesien word nie.

Die gevolg van die eeue-oue verwarring tussen twee eiesoortige menslike verhoudings (vriendskap en huwelik) was dat die Christelike kerke vriendskap gedevalueer het tot bloot ' $n$ voorbereiding vir die huwelik - soms selfs 'n bedreiging daarvan. Die konsekwensie daarvan was verarming, omdat dit intieme menslike kontak tot slegs één samelewingsverband en tot één verhouding, naamlik dié met jou man/vrou beperk het. Ongetroudes is hierdeur nog ernstiger geraak - hulle is tot eensaamheid verdoem. Enige intieme vriendskapsverhouding buite die huwelik is op hierdie wyse verdag gemaak.

As gevolg van hierdie ongegronde vrees word die huwelik geïsoleer, afgesny van die stimulering, ondersteuning en raad wat die huweliksgenote van mense (vriende) buite die huwelik kan ontvang. Daar word ook te veel van die huwelik verwag. Die huwelik kan oorspanne raak as dit die enigste manier is vir noue kontak en 'n wyse waarop 'n mens se probleme en gedagtes gedeel kan word. Juis dié feit - en nie ware vriendskap nie - kan daartoe lei dat buiteegtelike verhoudings aantreklik word.

Woldring (1994:162) lê die vinger op die pols as hy sê dat die wyd verbreide en diep gewortelde huweliks- en gesinsideologie (die geloof dat die sin van die lewe by uitstek in die huweliks- en die gesinslewe lê) vele in die Weste blind maak vir die betekenis van vriendskap.

Lewis (1990:68) sê tereg dat vriendskap en die huwelik nie verwar mag word nie. Vriendskap mag uiteindelik tot 'n huwelik ontwikkel. Die blote feit dat dit tot 'n huwelik ontwikkel, beteken dat dit iets van 'n ander aard geword het.

Van der Walt (2000:421) merk op dat nabyheid en liefde ook moontlik is sonder fisieke, seksuele gemeenskap eie aan die huwelik. Intimiteit is nie dieselfde as seks nie - selfs nie in die huwelik nie. Selfs wanneer ' $n$ mens getroud is, is dit nog moontlik en nodig - om ook ander (vriende, familie, jou naaste) lief te hê. Dit is buite-egtelike seks wat verkeerd is, nie buite-egtelike liefde nie!

Olthuis vat dit soos volg saam: 
We need to recognize the God-willed possibility of friendship being friendship; marriage, marriage, and family, family. Certainly in actual living they are linked to one another, but this very intertwinement reveals that the contours of the husband-wife relationship are not identical with those of father-mother and friend-friend relations. Troth plays a key role in all three relationships, but the troth in marriage is different from the troth in friendship and the troth in family. Since each of these relationships are unique, none can be defined in terms of the others (Olthuis, 1975:123).

Vergelyk ook Olthuis (1986) waarin hy op hierdie gedagtes, veral met betrekking tot die huwelik, voortbou.

'n Reformatoriese samelewingsfilosofie (vgl. Dooyeweerd, 1986) kan help om die onderskeid nog duideliker te maak. Vriendskap, huwelik en gesin is al drie (vgl. Olthuis, 1975:123) eties gekwalifiseerd. (Die norm is wedersydse trou teenoor mekaar.) Die etiese is die leidende funksie of modaliteit. Hulle funderingsfunksies verskil egter.

Vriendskap is gegrond op wedersydse psigiese aantrekkingskrag. Blote geesverwantskap is egter nie genoeg vir vriendskap nie, maar wel wedersydse trou.

By die huwelik is die biotiese die funderende. Op die biologiese onderbou is die seksuele moontlik, wat psigies verdiep en eties ontsluit word. Ook in hierdie opsig is die funderende nie die belangrikste nie. Wedersydse trou behoort tot geslagtelike eenwording te lei en nie omgekeerd nie. Seks skep nie trou nie. Die omgekeerde is egter die geval, want seksuele omgang bevestig, versterk en verdiep die belofte van getrouheid aan mekaar.

In die geval van die gesin is die funderende die biotiese (bloedverwantskap). Dit moet egter ontsluit word tot die sosiale en uiteindelik die etiese.

Al drie is dus etiese liefdesverhoudings, maar die liefde tussen vriende is van ' $n$ ander aard as dié tussen huweliksgenote. Dit verskil ook van ouerliefde tot kinders, kinderliefde vir hulle ouers en broeder/susterliefde tussen kinders onderling in die gesinslewe.

\subsection{Vriendskap en broederlike/susterlike liefde}

Vriendskap is een manier om vir die naaste 'n medemens te wees. 'n Ander manier is om vir jou naaste ' $n$ broeder/suster in die geloof te wees. 
Geesink (Deel 2, 1931:296) meen dat een van die redes waarom daar so min aandag aan vriendskap binne die Christendom gegee word, die feit is dat vriendskap moes wyk vir broederliefde.

Die ander "oplossing" (wat Geesink nie noem nie) is om al jou broeders/susters in die geloof ook as jou vriende/vriendinne te beskou. Baie Christene dink nog steeds, verkeerdelik, dat hulle almal in die(selfde) kerk as hulle vriende/vriendinne moet beskou. Die praktyk toon egter aan dat vriendskap en broederskap nie verwar behoort te word nie. Daar is baie opregte Christene met wie 'n mens nie graag vriende sal wil wees nie, omdat ' $n$ mens nie tot hulle aangetrokke voel nie - dit is nie noodwendig verkeerd nie. Dit hang af wat met die feitelike situasie gedoen word. As 'n mens aan jou vriende/vriendinne 'n spesiale plek in die kerk probeer gee en diegene wat nie jou vriende is nie ignoreer, dan is dit verkeerd. Hoewel alle kerklidmate nie jou vriende kan wees nie, is hulle almal nog steeds jou medegelowiges, wat met broederlike/susterlike liefde behandel moet word. (Vgl. byvoorbeeld Rom. 12:10; 1 Tess. 4:9; 2 Pet. 1:7 en Heb. 13:1.) Broeders en susters behoort mekaar te ondersteun, te bemoedig en opreg lief te hê.

Indien 'n mens egter dink dat elke medegelowige jou vriend/vriendin moet wees, sal jy 'n slegte gewete hê, omdat net 'n paar werklik jou vriende in die ware sin van die woord kan wees. (Vriendskap is weens sy aard selektief - dit gee voorkeur aan sekere mense.) In so 'n geval weet 'n mens nie werklik wat vriendskap is nie. 'n Nog groter gevaar is dat die kerk sy karakter kan verloor, omdat dit in 'n "klub van vriendjies" kan ontaard.

'n Struktuuranalise vanuit die Reformatoriese filososfie kan sake in hierdie opsig duideliker maak. Die kerk is 'n samelewingsverband waarvan die geloof die leidende funksie is, terwyl dit sosiaal gefundeerd is. Die kwalifiserende funksie in die geval van vriendskap is die etiese (trou), terwyl dit op wedersydse psigiese aantrekkingskrag (geesverwantskap) gegrond is. Elke samelewingsverband het aan al die aspekte of modaliteite van die werklikheid deel (bv. die juridiese, ekonomiese, linguale, sosiale, psigiese, biologiese, ensovoorts), maar elke samelewingsverband is uniek en word van ander onderskei, omdat dit 'n eie bestemmings-/ leidende/kwalifiserende en 'n eie funderingsfunksie het wat dit tipeer.

Die konklusie is dus: elkeen wat op 'n mens se pad kom, is jou naaste, baie is ook jou susters/broeders, maar slegs enkeles kan ook jou vriendinne/vriende wees. 
Nadat die verskil en verband tussen vriendskap en ander menslike liefdesverhoudings uitgespel is en die verwarrings uit die weg geruim is, is dit nodig om meer spesifiek te let op wat vriendskap eintlik is, sodat dit in ere herstel kan word.

\section{Wat vriendskap is}

'n Duideliker omskrywing is belangrik, omdat daar soveel verwarring heers. Talle skrywers skryf roerend oor vriendskap, sonder om duidelik te maak wat hulle presies daaronder verstaan.

\section{1 'n Intermenslike verhouding}

In die eerste plek is dit belangrik om te stel dat vriendskap 'n Goddelik verordende intermenslike verhouding is. Hierdie verhouding berus nie op menslike willekeur nie.

\subsection{Deur wedersydse trou gekwalifiseer}

In die tweede plek geld God se norm van trou vir hierdie verhouding. Anders gestel: Die sentrale liefdesgebod moet op hierdie terrein in die vorm van trou gestalte kry of gepositiveer word.

Die meeste skrywers (bv. Lewis, 1990; Olthuis, 1975; Van der Walt, 2000 en Woldring, 1994) beskou trou as die kern van vriendskap. Olthuis (1975:110) sê byvoorbeeld "troth characterizes, constitutes and qualifies" vriendskap. Geesink (Deel 2, 1931:296) skryf ook "Echte ... vriendschap, gefundeerd in sympathie voor wederzijdsche individualiteit, schept een verhouding van vertrouwen en trouw, zodat men zich op elkander verlaten kan ...". Woldring (1994:175, $176,177)$, wat vriendskap net as "wederkerige liefde" omskryf, se definisie is nog te vaag, omdat dit ook vir ander verhoudings (soos byvoorbeeld die huwelik en gesin) geld.

\subsection{In geesverwantskap gefundeer}

In die derde plek het vriendskap egter ook 'n bepaalde fundering. (Dit sien Woldring ook nie raak nie.) Lewis (vgl. 1990:62-68) behandel dit egter in detail. Vriende word volgens hom deur iets innerliks of geesteliks saamgebind wat moeilik onder woorde gebring kan word. Hierdie saambinding is méér as net gemeenskaplike belangstellings. Vriende deel 'n gemeenskaplike lewensvisie. (Van der Walt, 2000:420 praat in dié verband van "wedersydse geesverwantskap".) Lewis (1990:68) praat van "affection", wat volgens hom die matriks of voedingsbodem is 
waarop vriendskap ontwikkel. Hiermee slaan hy die spyker op die kop.

Olthuis $(1975: 110,111)$ omskryf die voorwaarde van wedersydse geesverwantskap só:

... psychic attraction or congeniality is the foundation for friendship. It can not be forced: either people are attracted to each other or they are not. Still, this sudden attraction is not yet friendship; it is merely the first spark which will eventually produce the flame of friendship.

\section{4 'n Samevattende omskrywing}

Met die volgende omskrywing van Olthuis (1975:112) word graag instemming betuig: "Friendship is a pledged vow of troth between two persons based upon psychic congeniality" (vgl. ook Olthuis, 1975:114 waar hy sê dat hierdie struktuur van vriendskap, as 'n gawe van God, onaantasbaar is).

Uit hierdie kernagtige omskrywing volg baie ander eienskappe van vriendskap:

- die belofte van trou is gewoonlik onuitgesproke en tog wéét 'n mens wie jou vriende is;

- vriendskapstrou het tyd nodig om te ontwikkel;

- sonder om daarna te vra, ondersteun vriende mekaar;

- dit is iets spontaan wat vreugde verdubbel en hartseer deel;

- vriende respekteer mekaar en daarom pas manipulasie nie in so 'n verhouding nie;

- dit beteken egter nie dat 'n vriend alles wat 'n mens sê en doen, eenvoudig aanvaar nie;

- dit is 'n verhouding wat gekenmerk word deur intimiteit, openheid, betrokkenheid, solidariteit en duursaamheid.

\subsection{Vriendskap het deel aan al die fasette van die werklikheid}

'n Vierde belangrike punt wat beklemtoon moet word, is die volgende: omdat vriendskap iets werkliks is, weerspieël dit al die verskillende kante van die werklikheid of het dit deel daaraan. In die Reformatoriese filosofie word (vanaf die laagste na die hoogste) die volgende fasette of modaliteite onderskei: 
(1) die numeriese; (2) die ruimtelike; (3) die fisiese; (4) die biotiese; (5) die psigiese (= die funderende funksie by vriendskap); (6) die logiese; (7) die historiese; (8) die linguale; (9) die sosiale; (10) die ekonomiese; (11) die estetiese; (12) die juridiese; (13) die etiese (= leidende funksie by vriendskap) en (14) die godsdienstige/geloof.

Ruimte ontbreek hier om aan te toon dat, hoewel net twee van hierdie fasette vrienskap tipeer, elkeen van hulle 'n plek het in 'n vriendskapsverhouding. Verskillende wetenskappe (vgl. 3.2) kan vriendskap vanuit 'n godsdienstige, juridiese, estetiese, ekonomiese, sosiale en al die ander hoeke bestudeer. Vriendskap kan byvoorbeeld groot fisies-biotiese waarde hê. Linden (2003:162-164) toon aan dat navorsing reeds oortuigend bewys het dat vriendskap nie net ernstige siektes kan voorkom nie, maar ook 'n belangrike rol speel in die genesingsproses ná ernstige mediese ingrype.

Geld dit vir enige soort vriendskap? Met ander woorde, is enige soort vriendskap goed en reg?

\section{Aanvaarbare en onaanvaarbare vorme van vriendskap}

Vriendskappe kan goed of sleg wees, aanvaarbaar of onaanvaarbaar. Selfs ' $n$ bende diewe kan nie anders as om tot 'n mate God se norm vir vriendskap, naamlik wedersydse trou, te handhaaf nie, anders sou hulle mekaar verraai en van mekaar begin steel. So 'n verhouding is struktureel wel 'n soort vriendskap, maar die normatiewe rigting is verkeerd en daarom is dit onaanvaarbaar. Tereg merk Lewis (1990:75) op dat vriendskap sowel "a school of virtue and a school of vice" kan wees.

\subsection{Belangrike invloed van die samelewing op vriendskap}

Ter inleiding moet gestel word dat die tydsgewrig en samelewing waarin 'n mens leef, 'n belangrike rol speel in die vorms wat vriendskappe aanneem. Veral Woldring (1994:120, 158) toon duidelik aan dat vriendskappe by verskillende volke en in verskillende tydperke verskillende gestaltes aanneem. Die vorms van vriendskap verskil ook by verskillende maatskaplike groeperings, soos byvoorbeeld in aristokratiese kringe, onder hande-arbeiders en ander beroepsgroepe. Vriendskap is nie alleen die uiting van individuele behoeftes nie, maar ook die resultaat van maatskaplike omstandighede en prosesse. 
In die Middeleeuse riddertyd was die geldende opvattings oor krag, trou en eer byvoorbeeld bevorderlik vir heroïese vriendskappe. Tye van konflik en omwentelinge kweek gewoonlik vriendskappe gekenmerk deur moed en opofferingsgesindheid.

Gedurende die negentiende en vroeë twintigste eeu was vriendskappe veral gegrond op sosiale status (vergelyk byvoorbeeld die oorskatting van die aristokrasie). In die twintigste eeu was politieke (ideologiese) vriendskappe aanvanklik belangrik, terwyl dit later al meer op 'n ekonomiese (materialistiese) basis gebou is.

In die huidige Westerse wêreld staan veral twee dinge voorop, naamlik vriende stel mekaar se geselskap (die sosiale) op prys en vriendskap word steeds meer pragmaties benader - dit moet vir mekaar nuttig wees, byvoorbeeld gemeenskaplike belange en dit moet materiële voordeel inhou (vgl. Woldring, 1994:12, 13). Watter soort vriendskappe gaan ons huidige Suid-Afrikaanse samelewing oplewer?

Tereg merk Woldring egter ook op dat 'n samelewing nie net bepaalde vriendskappe skep nie, maar dat die soort vriendskappe wat ons koester, ook 'n groot invloed kan hê op die samelewing waarin ons lewe - des te meer 'n rede om te onderskei tussen aanvaarbare en onaanvaarbare vriendskappe.

\subsection{Verskillende vorme van aanvaarbare vriendskappe}

Hoewel daar baie goeie vorms van vriendskap is, word slegs jeugvriendskap en vriendskap met die teenoorgestelde geslag as voorbeelde genoem.

\subsubsection{Jeugvriendskap}

Hoewel skool- en adolossensievriendskappe nie die diepte en duursaamheid van ryp, volwasse vriendskap ken nie - hulle word maklik gesluit en maklik weer verbreek - is hulle tog waardevol. Hierdie vriendskappe help kinders om hulle gebondenheid aan slegs hulle ouers te ontgroei, hulle ervaringswêreld te verbreed, hulle leer hulself beter ken, hulle leer om met ander om te gaan en op dié wyse na volwassenheid te ontwikkel. Die proses van identiteitsvorming, waarin vriendskap 'n belangrike rol speel, vind egter nie net gedurende die kinder- en jeugjare plaas nie - dit word ook in die volwasse lewe voortgesit. 


\subsubsection{Vriendskap met die teenoorgestelde geslag}

Op die vraag of ongetroudes en veral getroudes 'n vriendskap mag hê met iemand van die teenoorgestelde geslag, word verskillende antwoorde gegee. Brillenburg Wurth (vgl. 1953:142, 143) beskou dit nie as prinsipieel verkeerd nie, maar omdat menswees en geslagtelikheid in die praktyk nie geskei kan word nie, keur hy sulke verhoudings ten sterkste af.

Ook Olthuis erken dat getroudes en ongetroudes moeilik 'n vriendskapsverhouding met iemand van 'n ander geslag kan onderhou. Die rede is dat mense nie duidelik tussen vriendskap en die seksuele (wat by die huwelik hoort) onderskei nie. Sulke verhoudings (tussen persone van verskillende geslagte) is gevolglik verdag. Vriendskap oor geslagsgrense is egter vir hom aanvaarbaar. Olthuis $(1975: 115,116)$ waarsku egter ook dat intieme fisieke kontak (wat hy ongelukkig nie verder omskryf nie - bedoel hy daarmee seksuele kontak?) tussen 'n man en vrou of twee mans of twee vroue, 'n gevaarteken is dat die vriende nie meer die norm van vriendskap handhaaf nie en dus liewer die verhouding moet verbreek.

\subsection{Verskillende vorms van onaanvaarbare vriendskappe}

Vriendskap kan deur die Heilige Gees óf deur die gees van die duiwel geïnspireer wees. Laasgenoemde vorms van vriendskappe kan aan al die strukturele vereistes van vriendskap voldoen (die lid van 'n rowerbende kan byvoorbeeld bereid wees om sy eie lewe vir sy vriend te gee), maar die religieuse rigting daarvan is verkeerd en daarom is dit onaanvaarbaar. Dit gaan in hierdie opsig egter nie oor sulke duidelik verkeerde vorme van vriendskap nie, maar oor meer subtiele - en dus gevaarliker - soorte.

\subsubsection{Kennisse en kamerade is nie vriende nie}

Baie mense wat ons graag vriende noem, is nie werklik vriende (soos alreeds beskryf) nie. Met kennisse, kamerade, sakegenote, ensovoorts, kan 'n mens 'n gemaklike, hartlike verhouding hê, maar die belofte van trou (die kwalifiserende kenmerk) ontbreek dikwels. Sulke verhoudings is meestal logies, polities, sosiaal of ekonomies en nie eties gekwalifiseerd nie.

Linden (2003:158) noem as voorbeeld hiervan "buddyhood", wat 'n mens vanaf die haarkappersalon tot die kroeg aantref. Hierdie tipe verhouding bereik egter nooit die diepte, duursaamheid en intimiteit 
van ware vriendskap nie, omdat dit vir die maats bloot om eie plesier (die sosiale) en nut (die pragmatiese) gaan.

\subsubsection{Klieke is gevaarlik}

Kliekvorming is by die jeug iets normaals, eie aan die aard van hulle ontwikkelingsfase, maar dit is van verbygaande aard. Brillenburg Wurth (1953:139) waarsku tereg dat 'n kliek nie meer 'n vriendskapsverhouding is nie, omdat nie liefde nie, maar hoogmoed, selfsug en groepsegoïsme dit beheers. Ook Lewis (1990:74, 75) waarsku dat klieke tot hulleself ingekeer is, mekaar op die skouer klop, in hoogmoed op die buitewêreld neersien en dat hulle doof raak vir enige korreksie van buite af.

Omdat hierdie 'n uiters gevaarlike verskynsel is en Olthuis (1975: $125,126)$ dit besonder raak tipeer, word hy breedvoerig aangehaal:

Sometimes friends form cliques that turn in on themselves to the exclusion of everyone else. The clique overflows the bounds of friendship and attempts to swallow up all other relations by becoming a privileged circle serving itself - an elite that doesn't care what anyone else does, says or thinks. The clique emasculates true friendship for the sake of selfish pride. Cliques offer the prestige of belonging to the ruling coterie, of obtaining positions of esteem and honor, of having the privileges of power. Personal growth, troth, and enrichment - the plant of friendship are choked by the weeds of corporate haughtiness and selfaggrandizement. The group exists for the group, a self-elected aristocracy. Everyone outside the circle must be reminded frequently that he is not in it ... Such false friendships so misuse the relationship that they become tyrannical.

\subsubsection{Hedendaagse "vriendskappe"}

'n Afsonderlike artikel sal nodig wees om op die aard van allerlei moderne soorte vriendskappe in te gaan. Die hedendaagse samelewing bied moontlikhede om met ander in verhouding te tree, waarvan ons voorgeslagte nie eers kon droom nie. Deur middel van e-pos en chat rooms kom 'n mens in kontak met 'n onbeperkte aantal mense en kan jy jou diepste emosies sonder enige inhibisie uitspreek. Sulke verhoudings ontstaan heel waarskynlik as gevolg van die groot gebrek aan ware vriendskap in ons hedendaagse individualistiese samelewing. Kan ons dit egter "vriendskap" noem?

Linden (2003:157,158) twyfel nie en stel duidelik waarom elektroniese "vriendskap" nie as vriendskap kan kwalifiseer nie: 
Though one may experience emotional release in a chat room, such exchanges cannot have true reciprocity ... Cyber friendships lack commitment; the society of cyberspace is a faceless society and can easily be a faithless one ... such friendships can become a form of electronic egotism, often degenerating into isolated narcissism ... Despite expressing depth and feeling, distance and anonymity allow these relationships to be intrinsically superficial.

Hiermee word weereens die vraag opgeroep waarom vrienskap vandag so skaars geword het - so skaars dat mense selfs hul toevlug tot kurbernetiese vriendskappe neem.

\section{Waarom vriendskap vandag so skaars geword het}

Heelwat faktore wat vriendskap kan benadeel, is reeds genoem. Daaronder is die feit dat die Christendom vriendskap oor die algemeen onderskat en onderwaardeer het; dat dit met ander menslike verhoudings verwar is en dus nie in sy rykdom en waarde kon ontplooi nie; vriendskap word ook met verhoudings vereenselwig wat nie werklik op egte vriendskap kan aanspraak maak nie.

Die huidige Westerse kultuur hou ongetwyfeld nadelige gevolge in. (Vooraf is reeds daarop gewys dat 'n bepaalde samelewing vriendskap wesenlik kan beïnvloed.) Die oorsake word net puntsgewys genoem, omdat die implikasies vir vriendskap duidelik behoort te wees.

Die volgende is beskrywings wat die hedendaagse Westerse samelewing kenmerk:

- Individualisme, waarin alles om die eie ek draai (egoïsme), voer die bo-toon.

- Dit is ekonomisties-materialisties en pragmaties, omdat dit alles in terme van die nuttigheid daarvan weeg.

- Dit is gebou op meedoënlose kompetisie.

- Verder is dit 'n ontsettende gejaagde samelewing.

- Dit is verder 'n baie mobiele kultuur - mense bly nie meer lank in dieselfde beroep of op dieselfde plek nie.

- Dit is 'n tegnokratiese samelewing wat medemenslikheid offer op die altaar van saaklikheid, doeltreffenheid en resultate, met gevolglike leegheid en eensaamheid. 
- Die elektroniese media (TV, selfoon en rekenaar) vervang of verdring dikwels persoonlike menslike kontak.

- Werk (beroepe) word so oorbeklemtoon dat ander menslike verhoudings afgeskeep word.

- Dit is 'n terapeutiese kultuur - een waarin allerlei spesialiste en terapeute mense se persoonlike probleme moet oplos en nie meer die raad van vriende nie.

- Dit is ten diepste 'n vreesbevange kultuur waarin mense bang is om hulself vir ander oop te stel, omdat hulle teleurgesteld mag wees of selfs diep kan seerkry.

- Verder is dit 'n seksbehepte kultuur, sodat egte vriendskap daaronder ly.

- In verhouding met die meeste voorafgaande beskawings, is die huidige Westerse kultuur uiters oppervlakkig.

- Verskille van politieke en rase-aard belemmer (veral in SuidAfrika) vriendskap.

- Ten slotte is dit 'n koue, liefdelose samelewing met 'n skreiende gebrek aan betrokkenheid by die medemens.

Olthuis se konklusie is dat die soort vriendskappe van vroeëre eeue vandag nie meer moontlik is nie. Ons lewe in 'n samelewing wat, indien dit nie vyandig is teenoor vriendskap nie, vriendskap in alle geval nie stimuleer nie. "Society just does not allow the freedom for the growth and development of genuine friendships" (Olthuis, 1975:127).

Die vraag is of hierdie hartseer situasie maar gedweë aanvaar moet word. Ten slotte dus enkele gedagtes daaroor.

\section{7. 'n Wonderlike gawe en groot opgawe}

Die dilemma is die volgende: Omdat baie mense as gevolg van bogenoemde faktore selde of ooit die vreugde van opregte vriendskappe ervaar, waardeer en ontwikkel hulle dit ook nie. Omdat hulle dit nie probeer doen nie, sal hulle ook nooit die groot waarde van vriendskap self ervaar nie. Twee belangrike punte moet in hierdie verband beklemtoon word.

\section{1 'n Wonderlike gawe van God self}

God weet wat die mens nodig het, anders sou iets soos vriendskap nie bestaan het nie. Hy weet dat sonder hegte vriendskappe min 
mense kan oorleef. Dit gaan egter nie bloot om oorlewing nie. Met hierdie besondere goddelike gawe word die lewe verryk en verdiep en ervaar ' $n$ mens ' $n$ besondere soort vreugde. Indien vriendskap ' $n$ gawe van God self is, is dit sonde as dit nie in dankbaarheid aanvaar, ontwikkel en gekoester word nie. Om dit ná te laat, geskied ook tot 'n mens se eie nadeel. Hierdie groot gawe van God is dus terselfdertyd 'n opgawe of opdrag - dit is nie 'n blote opsie nie.

\section{2 'n Groot verantwoordelikheid}

In hierdie verband moet 'n mens nie net dink aan die groot leemte in jou eie lewe wanneer jy self sonder vriende probeer leef nie. 'n Mens moet ook dink wat jy ander aandoen deur hulle van jou vriendskap te beroof. Olthuis skryf dat om vrienskap van ander te weerhou

$\ldots$ is to condemn them to a life of aching loneliness and pain which others cannot even imagine. For them friendship could mean a bounteous share in the spice and joy of life. For many it could even mean the difference between experiencing life as a cruel trick or a rare treat (Olthuis, 1975:128).

Die Christelike gemeenskap moet aktief omstandighede skep wat vriendskap weer kan laat bloei. Dit kan op baie maniere gedoen word. Miskien is die belangrikste dat die samelewing weer duidelik herinner word aan die wese van vriendskap, naamlik wedersydse trou. As ' $n$ mens in 'n samelewing leef waarin jy feitlik niemand meer op haar/sy woord kan neem nie, hoe kan vriendskap, waarin vertroue alles is, oorleef? Daarom sê Olthuis (1975:129): "Troth [fidelity] must be recovered ... our culture requires a new life-style a biblical life-style - in which keeping troth is an essential mark."

\section{Geraadpleegde bronne}

AALDERS, W.J. 1947. Handboek der ethiek. Amsterdam: Holland.

ADAMS, A., IRWIN, C.H. \& WALTERS, S., eds. 1968. Cruden's complete concordance to the Old and the New Testaments. Grand Rapids: Zondervan.

ANDRESEN, C., red. 1973. Bibliographia Augustiniana. Darmstadt: Wissenschaftliche Buchgesellschaft.

ANONIEM. 1982. Nelson's three-in-one Bible reference companion. Nashville: Nelson.

BRILLENBURG WURTH, G. 1948-1951. Het Christelijk leven (3 dele). Kampen: Kok.

BRILLENBURG WURTH, G. 1953. Gestalten der liefde. Kampen: Kok.

BRUNNER, E. 1949. The divine imperative; a study in Christian ethics. London: Lutterworth. 
DECKER, M. 1997. Friends for life; offering support and friendship. AIDS Bulletin, 6(1 \& 2):44-45.

DOOYEWEERD, H. 1986. A Christian theory of social institutions. La Jolla, California : The Herman Dooyeweerd Foundation.

DREYER, Y. 2002. Women leadership from a pastoral perspective of friendship. Hervormde Teologiese Studies, 58(1):43-61.

DUNSTAN, L.V. \& NIEUWOUDT, J. 1993. The relationship between indexes of childhood friendship and biographical, personality and behavioural variables. Social Work, 29(1):75-82.

FAIRWEATHER, I.C.M. \& MCDONALD, J.I.H. 1984. The quest for Christian ethics. Edinburg: Handsel.

GEESINK, W. 1907-1908. Van 's Heeren ordinantiën (3 dele). Amsterdam: Kirchner.

GEESINK, W. 1931. Gereformeerde ethiek (2 dele). Kampen: Kok.

HARTMANN, N. 1955. Ordo amoris; Zur Augustinischen Wesensbestimmung des Sittlichen. Wissenschaft und Weisheit, 18:1-13; 108-121.

HENRY, C.F.H. 1965. Christian personal ethics. Grand Rapids: Eerdmans.

KIERKEGAARD, S. 1962. Works of love. New York: Harper.

LADIKOS, A. 2000. Aristotle's approach on justice and friendship: food for modern criminological thought. Acta Criminologica, 12(3):45-51.

LEWIS, C.S. 1990. The four loves. Glasgow: Collins.

LIDDELL, C. 1987. Friendship and social interaction. South African Journal of Psychology, 17(2):80-81.

LINDEN, G.W. 2003. Friendship. Journal of Individual Psychology, 59(2):156165.

McNAMARA, M.A. 1958. Friendship in Augustine. Fribourg: University Press. (Studia Freibourgensia, New Series 20.)

NYGREN, A. 1957. Agape and eros. London: SPCK.

OLTHUIS, J.H. 1975. I pledge you my troth; a Christian view of marriage, family, friendship. New York: Harper \& Row.

OLTHUIS, J.H. 1986. Keeping our troth; staying in love through the five stages of marriage. San Francisco: Harper \& Row.

PIENAAR, N. 1995. Friendship through sport. Salut, 2(3):60-61.

REID, C.L. 1981. Choice and action; an introduction to ethics. New York: Macmillan.

RITTER, J. 1972. Historisches Wörterbuch der Philosophie. (T. 2, sub voce Freund und Freundschaft. p. 1103-1114.) Darmstadt: Wissenschaftliche Buchgesellschaft.

SCHIPPERS, R. 1955. De Gereformeerde Zede. Kampen: Kok.

STEYN, L. 1996. Friendship through sport. Salut, 3(5):36-37.

STOB, H. 1978. Ethical reflections; essays on moral themes. Grand Rapids: Eerdmans.

STORTZ, M.E. 2002. Geographies of friendship; Arendt and Aristotle. Dialog : A Journal of Theology, 41(3):225-230.

VAN DER WALT, B.J. 2000. Visie op die werklikheid; die bevrydende krag van 'n Christelike lewensbeskouing en filosofie. Potchefstroom: Instituut vir Reformatoriese Studie.

VAN WYK, J.H. 1986. Gesindheid en gestalte. Pretoria: N.G. Kerkboekhandel.

VAN WYK, J.H. 1991. Moraliteit en verantwoordelikheid. Potchefstroom: PU vir $\mathrm{CHO}$. 
VAN WYK, J.H. 1998. Etiek in eenvoud; gesprekke oor morele vraagstukke. Noordbrug: Administratiewe Buro van die Geref. Kerke in Suid-Afrika. (Potchefstroomse Teologiese Publikasies.)

VAN WYK, J.H. 1999. Lewe in liefde; moraliteit vir die markplein. Potchefstroom: Instituut vir Reformatoriese Studie.

VAN WYK, J.H. 2001. Etiek en eksistensie in koninkryksperspektief. Noordbrug: Administratiewe Buro van die Geref. Kerke in Suid-Afrika. (Potchefstroomse Teologiese Publikasies.)

VON MEYENFELDT, F.H. s.j. De Christelijke levenswandel. Wageningen : Zomer \& Keunings.

WOLDRING, H.E.S. 1994. Vriendschap door de eeuwen heen; wijsgerige beschouwingen over vriendschap als gave en opgave. Baarn: Ambo.

WUTHNOW, R. 2003. Overcoming status distinctions? Religious involvement, social class, race and ethnicity in friendship patterns. Sociology of Religion, 64(4):423-442.

\section{Kernbegrippe:}

getrouheid/trou

liefde; tot naaste; eggenote; geloofsgenote

vriendskap; 'n gebrek aan

vriendskap; die herstel van

\section{Key concepts:}

\section{fidelity/troth}

friendship; lack of

friendship; restoration of

love; towards neighbour; spouse; fellow believers 